\title{
ANTIBAKTERI SENYAWA FENOLIK DARI ALANG -ALANG (Imperata cylindrica)
}

\author{
Jhon Patar Sinurat ${ }^{1}$, Suci Wulandari ${ }^{2}$, Rinaldo Berutu ${ }^{3}$ \\ Institut Kesehatan Medistra Lubuk Pakam, Deli Serdang, Sumatera Utara. \\ e-mail : jhonpatar12@gmail.com \\ DOI $10.35451 / \mathrm{jfm} . v 3 i 2.684$
}

\begin{abstract}
Phytochemical screening test proved that the extract of Reeds (Imperata cylindrica) contained phenolic compounds tested using $5 \% \mathrm{FeCl}_{3}$ reagent. Antibacterial test using agar diffusion method against Reeds extract in DMSO solvent. The phenolic compounds obtained from the saputangan leaves Reeds extract were 36.96 grams after undergoing maceration. Reeds extract of phenolic compounds with concentrations (200; 100; 50 and 25 ppm) had strength antibacterial where the average inhibition zone of Staphylococcus aureus bacteria was $10.0 \mathrm{~mm}$ and the average inhibition zone was at Escherichia coli bacteria measuring $10.3 \mathrm{~mm}$.
\end{abstract}

Keywords: Screening, Phenolic, Antibacterial.

\section{PENDAhUlUAN}

Tumbuhan merupakan sumber penting dalam menghasilkan senyawa obat-obatan, hal ini disebabkan tumbuhan mengandung senyawa bioaktif (Mahidol et al., 2002). Berbagai senyawa bioaktif telah dianalisis, diisolasi dan diekstraksi agar dapat digunakan bioaktivitasnya sebagai antimikroba (Keller dan Nugraha, 2016).

Masih banyak jenis tanaman hias yang belum dimanfaatkan secara maksimal dari sisi nilai ekonomisnya, yang tidak lain adalah tanaman hias yang memiliki khasiat obat. Beberapa jenis tanaman hias memiliki fungsi sebagai tanaman hias dan juga sebagai bahan obat untuk beberapa jenis penyakit yang umum dijumpai dalam masyarakat. Kegunaan dari tanaman hias tersebut tidaklah sama disebabkan kandungan metabolitnya berbeda-beda. (Bambang dan Heru, 2011).

Indonesia memiliki tanah yang subur yang memiliki keragaman hayati terbanyak. Tidak semua tumbuhan dapat dimanfaatkan bagi kesehatan (Heru, 2012). Senyawa fenolik adalah senyawa yang memiliki gugus hidroksil yang melekat pada cincin aromatis. Senyawa fenolik dapat dijumpai pada batang, daun, bunga, dan buah tanaman (Vermeris dan Nicholson, 2016). Antibakteri adalah zat yang mampu mencegah atau menghambat 
jasad renik yang berasal dari sintesis ataupun senyawa non organik.

Penelitian yang dilakukan oleh Dzoyem et al. (2017) terhadap senyawa fenolik dari Entada abyssinica yang memiliki bioaktivitas sebagai antibakteri. Beberapa penjelasan diatas membuat peneliti ingin menguji antibakteri dari ekstrak alang-alang.

\section{METODE}

\section{Bahan dan Peralatan}

Bahan: Serbuk alang-alang, metanol, DMSO, bakteri Staphylococcus aureus dan Escherichia coli dan $\mathrm{FeCl} 3$ $5 \%$.

Peralatan: Maserator, Penangas air, Rotary Evaporator, Cawan Petri, Kertas Cakram dan Autoklaf.

\section{Preparasi Sampel}

Sampel alang-alang (Imperata cylindrica) dilakukan determinasi untuk memastikan jenis tanaman secara ilmiah. Alang-alang dibersihkan, dikeringkan di tempat teduh, kemudian dihaluskan hingga diperoleh serbuk halus.

\section{Maserasi}

Sampel alang-alang dibuat menjadi serbuk sebanyak 2500 gram dimaserasi selama \pm 24 jam menggunakan pelarut metanol sebanyak 8 liter pada suhu kamar. Maserat disaring hingga diperoleh maserat yang bebas residu. Maserasi kembali dilakukan secara berulang dan diikuti skrining menggunakan $\mathrm{FeCl}_{3}$ 5\%. Ekstrak metanol dipekatkan dalam rotary evaporator dalam suhu $65^{\circ} \mathrm{C}$ dengan putaran $80 \mathrm{rpm}$. Ekstrak dilanjutkan penguapan hingga didapatkan ekstrak sebesar $200 \mathrm{~g}$.

\section{Pengujian Antibakteri}

Metode difusi agar digunakan dalam uji antibakteri ini. Sebanyak $0.1 \mathrm{ml}$, inokulum bakteri $S$. aureus dan $E$. coli diusapkan kedalam media nutrien agar. Dicelupkan kertas cakram ke dalam ekstrak DMSO alang-alang dengan konsentrasi 200; 100; 50 dan 25 ppm. Cakram ditempatkan pada media dikenai dengan bakteri, lalu diinkubasi pada suhu $35 \pm 2{ }^{\circ} \mathrm{C}$ selama 18 - 24 jam, selanjutnya zona hambat diukur diameternya..

\section{HASIL}

Kemampuan antibakteri ekstrak tumbuhan alang - alang terhadap bakteri Streptococcus aureus dan Escherichia coli dapat dilihat berdasarkan besarnya zona hambat yang dihasilkan pada media. Tabel 3.1 menunjukkan hasil zona hambat.

Tabel 3.1 zona hambat bakteri

\begin{tabular}{|c|c|c|c|}
\hline $\mathrm{N}$ & \multirow{2}{*}{ Konsentrasi } & \multicolumn{2}{|c|}{ Zona Hambat } \\
\hline 0 & & S.Aureus & E.Coli \\
\hline 1 & 200 ppm & $\begin{array}{c}10.6 \\
\mathrm{~mm}\end{array}$ & $10.9 \mathrm{~mm}$ \\
\hline 2 & 100 ppm & $\begin{array}{l}10.2 \\
\mathrm{~mm}\end{array}$ & $10.4 \mathrm{~mm}$ \\
\hline 3 & 50 ppm & $9.8 \mathrm{~mm}$ & $10.1 \mathrm{~mm}$ \\
\hline 4 & $25 \mathrm{ppm}$ & $9.4 \mathrm{~mm}$ & $9.8 \mathrm{~mm}$ \\
\hline
\end{tabular}

Ekstrak alang - alang senyawa fenolik dengan konsentrasi $(200,100$, 50 dan 25 ppm) memiliki kekuatan antibakteri pada level medium yang mana zona hambat rata-rata pada bakteri $S$. aureus sebesar $10.0 \mathrm{~mm}$ dan zona hambat rata-rata pada bakteri $\mathrm{E}$. coli sebesar $10.3 \mathrm{~mm}$. (Adelgrit T, 2018).

\section{PEMBAHASAN}

Besarnya zona hambat dapat dipengaruhi faktor seperti besarnya inokulum, waktu inkubasi, konsentrasi ekstrak, dan kekuatan antibakteri senyawa. Inokulum berbanding terbalik dengan zona hambat. Semakin besar konsentrasi maka kecepatan difusi senyawa semakin cepat. Konsentrasi ekstrak semakin besar maka daya 
antibakteri semakin kuat dan menyebabkan diameter zona hambat semaikn besar (jawetz, 2015).

Berdasarkan penelitian yang dilakukan Fu Li et al, 2016 menunjukkan bahwa antibakteri memiliki korelasi positif terhadap jumlah senyawa fenolik. Dilaporkan juga bahwa asam galat yang merupakan senyawa fenolik dapat menghambat pertumbuhan banyak bakteri, termasuk S. aureus, E. coli, P. aeruginosa, dan Salmonella typhi. Semua senyawa fenolik.

\section{KESIMPULAN}

Berdasarkan penelitian yang dilakukan maka terbukti senyawa fenolik ekstrak alang-alang mampu bertindak sebagai antibakteri kuat dengan zona hambat rata-rata bakteri Staphylococcus aureus adalah $10.0 \mathrm{~mm}$ dan Escherichia coli adalah 10,3 mm.

\section{DAFTAR PUSTAKA}

Jawetz. EJ, Melnick L, Adelberg EA, 2015. Microbiologi Untuk Profesi Kesehatan. Penerbit Buku Kedokteran EGC. Jakarta.

Keller PA, Nugraha AS, 2016. Revealing Indigenous Indonesian Traditional Medicine: anti-infectiveagents. Natural Product Communications, 6(12): 1953-1966.

Fu L, Lu W and Zhou X, 2016. Phenolic Compounds and In Vitro Antibacterial and Antioxidant Activities of Three Tropic Fruits: Persimmon, Guava, and Sweetsop. Hindawi Publishing Corporation BioMed Research International Volume 2016, Article ID 4287461, 9 pageshttp://dx.doi.org/10.1155/2 016/4287461.

Adelgrit Trisia, Regina Philyria, \& Angeline Novia Toemon, 2018. Uji Aktivitas Antibakteri Ekstrak Etanol Daun Guazuma ulmifolia Lam. terhadap Pertumbuhan S.aureus Dengan Metode Difusi Cakram.
Anterior Jurnal, Volume 17 Issue 2, page 136-143

Vermerris W, Nicholson R, 2016. Phenolic Compound Biochemistry. Springer. The Netherla 